\title{
Two Novel Donepezil-Lipoic Acid Hybrids: Synthesis, Anticholinesterase and Antioxidant Activities and Theoretical Studies
}

\author{
Bruna S. Terra, ${ }^{a}$ Pedro H. C. da Silva, ${ }^{a}$ Anna Tramarin, ${ }^{b}$ Lucas L. Franco, ${ }^{a}$ \\ Elaine F. F. da Cunha, ${ }^{c}$ Fernando Macedo Junior, ${ }^{d}$ Teodorico C. Ramalho, ${ }^{c}$ \\ Manuela Bartolini, ${ }^{b}$ Maria L. Bolognesi ${ }^{b}$ and Ângelo de Fátima*,a \\ ${ }^{a}$ Departamento de Química, Universidade Federal de Minas Gerais (UFMG), \\ Av. Pres. Antônio Carlos, 6627, 31270-901 Belo Horizonte-MG, Brazil \\ ${ }^{b}$ Department of Pharmacy and Biotechnology, Alma Mater Studiorum University of Bologna, \\ via Belmeloro, 6, 40126 Bologna, Italy \\ ${ }^{c}$ Departamento de Química, Universidade Federal de Lavras (UFLA), Av. Doutor Sylvio Menicucci, \\ 1001, Kennedy, 37200-000 Lavras-MG, Brazil \\ ${ }^{d}$ Departamento de Química, Universidade Estadual de Londrina (UEL), Rodovia Celso Garcia Cid, \\ $\operatorname{Pr} 445, \mathrm{~km}$ 380, 86057-970 Londrina-PR, Brazil
}

\begin{abstract}
Alzheimer disease (AD) is a complex disease related to multiple pathogenic mechanisms. A strategy to develop effective drugs is based on the so-called multi-target directed ligands (MTDL) by using hybrid compounds. So, in the present study, we have designed and synthesized two hybrids, containing the indanone-piperidine moiety of donepezil, a drug approved for the treatment of $\mathrm{AD}$, and the lipoic acid scaffold, an antioxidant compound endowed with neuroprotective effects. One hybrid was synthesized in four steps with $42 \%$ global yield, and the other hybrid in six steps with $19 \%$ global yield. The latter hybrid displayed moderate inhibitory activity against human acetylcholinesterase (hAChE) and greater activity against human butyrylcholinesterases (hBuChE). The selectivity for $\mathrm{hBuChE}$ was further rationalized by theoretical study. Importantly, the second hybrid showed a good antioxidant activity, exhibiting better ability in scavenging 2,2-diphenyl1-picrylhydrazyl (DPPH) radicals than lipoic acid.
\end{abstract}

Keywords: donepezil-lipoic acid hybrids, Alzheimer disease, multi-target directed ligands

\section{Introduction}

Alzheimer disease (AD) is the most common cause of dementia in aging population. It was estimated that, in 2010, about 35.6 millions of people suffered from dementia worldwide, and it is expected that this number might triplicate in the next 40 years. ${ }^{1}$ Patients affected by AD experience progressive cognitive impairment, such as a decline in short-term memory, loss of speech, language and motor coordination. ${ }^{2,3}$

$\mathrm{AD}$ is pathologically characterized by an extracellular deposition of $\beta$-amyloid ( $A \beta$ ) peptide into senile plaques, intracellular formation of neurofibrillary tangles (NFTs) containing a hyperphosphorylated form of Tau protein, oxidative stress, mitochondrial abnormality,

*e-mail: adefatima@qui.ufmg.br neuroinflammatory processes and neuronal loss, mainly affecting the frontal cortex and hippocampus. ${ }^{4,5} \mathrm{AD}$ is also characterized by a reduction of acetylcholine (ACh) levels, which is correlated with the cognitive symptoms. ${ }^{6}$

The "cholinergic hypothesis", proposed in 1982 by Bartus et al., ${ }^{7}$ postulated that the cognitive decline experienced by patients with AD resulted from a deficiency of acetylcholine or cholinergic neurotransmission. In humans, acetylcholine is degraded in the synaptic cleft by two main classes of cholinesterase enzymes: acetyl- (AChE) and butyryl- $(\mathrm{BuChE})^{8}$ cholinesterases.

Near the amyloid plaques and neurofibrillary tangles, an extensive oxidative stress has been observed ${ }^{9}$ which is a result of an altered balance of formation of reactive oxygen species (ROS) versus scavenging activity. ${ }^{5,10}$ The production of ROS is also related to calcium homeostasis; the misbalance of calcium influx affects the mitochondrial 
enzymes and ROS production is a normal part of the electron transport chain. However, excessive levels of these species damage proteins, lipids and nucleic acids. ${ }^{9}$

$\mathrm{AD}$ is a complex disease related to multiple pathogenic mechanisms involving different molecular targets. All the drugs approved so far are palliative and not curative. A strategy to develop effective drugs is based on the so-called multi-target directed ligands (MTDLs) ${ }^{11}$ approach. This strategy builds on the development of a single drug that can simultaneously interact with different targets. The advantages of this polypharmacological strategy, when compared with the administration of a combination of multiple drugs, are the reduction of the risk of drug-drug interactions and a simplification of the pharmacokinetic and pharmacodynamic studies. Moreover, the success rate of the treatment of a complex disease of the elderly, as AD, should be higher. ${ }^{12}$

Donepezil (Figure 1), a palliative drug approved in 1996, is indicated for the treatment of mild and moderate forms of AD. ${ }^{13}$ Its structure represents an attractive starting point for the rational design of new MTDLs that can inhibit $\mathrm{AChE}$ and, at the same time, interact with other targets involved in $\mathrm{AD}$ onset and progression. ${ }^{13,14}$

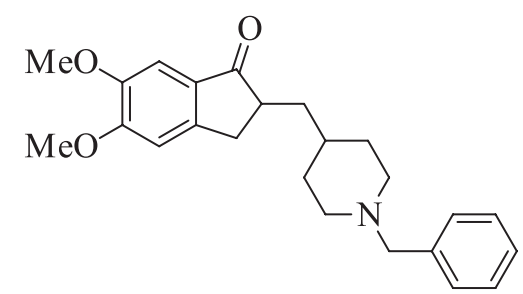

Figure 1. Chemical structure of donepezil.

Many prototypes for new drugs based on the hybridization strategy have been developed starting from donepezil fragments, i.e., indanone-piperidine moiety or piperidine-benzyl fragment. ${ }^{13}$ Furthermore, donepezil hybrids with tacrine, ${ }^{15,16}$ diaminobenzyl group,${ }^{17}$ ferulic acid, ${ }^{18}$ coumarin, ${ }^{19}$ among others ${ }^{13}$ have been prepared.

Hybrids containing the piperidine-benzyl moiety of donepezil and lipoic acid (LA) (Figure 2) were described by the groups of Kim et al., ${ }^{20}$ Lee et al., ${ }^{21}$ Prezzavento et $a l .,{ }^{22}$ and Estrada et $a l .{ }^{23}$ The hybrids showed activity against cholinesterase (ChE) enzymes, antagonism toward $\sigma 1$ receptors, $\beta$-secretase inhibition and antioxidant activity.

LA is a natural disulfide compound present in almost all foods from animal and vegetable sources. LA and its reduced form, dihydrolipoic acid (DHLA) (Figure 2), play an important role in pathological conditions characterized by oxidative stress, ${ }^{24,25}$ such as: (i) scavenger of ROS, (ii) capacity to increase the level of reduced glutathione and other antioxidant enzymes, (iii) downregulation of the inflammatory processes, (iv) scavenging of lipid peroxidation products, $(v)$ redox active transition metal chelation, ( $v i)$ increase of ACh production by activation of choline acetyltransferase. ${ }^{25}$ On the basis of such activities, LA can exert beneficial effects in AD, possibly stabilizing cognitive functions. ${ }^{26}$<smiles>O=C(O)CCCCC1CCSS1</smiles>

LA<smiles>O=C(O)CCCCC(S)CCS</smiles>

DHLA
Figure 2. Chemical structures of lipoic acid (LA) and of dihydrolipoic acid (DHLA).

Thus, LA is a good prototype to design new hybrids to combat $\mathrm{AD}$, and previously developed LA hybrids maintained the antioxidant activity and showed other beneficial activities such as inhibition of AChE and $\mathrm{BuChE}$ as well as neuroprotective and anti-inflammatory activity. ${ }^{27,28}$

In 2005 , Rosini et al. ${ }^{29}$ reported the synthesis of lipocrine, an LA-tacrine hybrid, which further inspired the development of other hybrids featuring an LA fragment connected with $N^{1}$-ethyl- $N^{1}$-(2-methoxy-benzyl)-hexane1,6-diamine moiety or with rivastigmine. ${ }^{26}$

Although there are works involving the hybridization of the benzyl-piperidine moiety of donepezil with LA, to our knowledge, there is no report on the hybridization of the indanone-piperidine moiety with LA. Therefore, in the present study, following a simple synthetic route, we have designed and synthesized two hybrids containing the indanone-piperidine moiety of donepezil and the LA scaffold with the aim of achieving new MTDLs for the treatment of AD. ${ }^{11}$ Here, we report their biological assessment on human AChE (hAChE), human BuChE (hBuChE), as well as the evaluation of their antioxidant activity using the 2,2-diphenyl-1-picrylhydrazyl (DPPH) assay. Finally, docking studies provided further insights of the binding mode of these novel donepezil-lipoic acid hybrids with $\mathrm{AChE}$ and $\mathrm{BuChE}$.

\section{Results and Discussion}

\section{Synthesis of hybrid compounds}

Two novel donepezil-LA hybrids, differing only by the linkage between the two units, were designed and synthesized. In the final hybrid structures, the indanone and piperidine fragments were preserved and the benzyl group was replaced by the LA portion (Figure 3). 


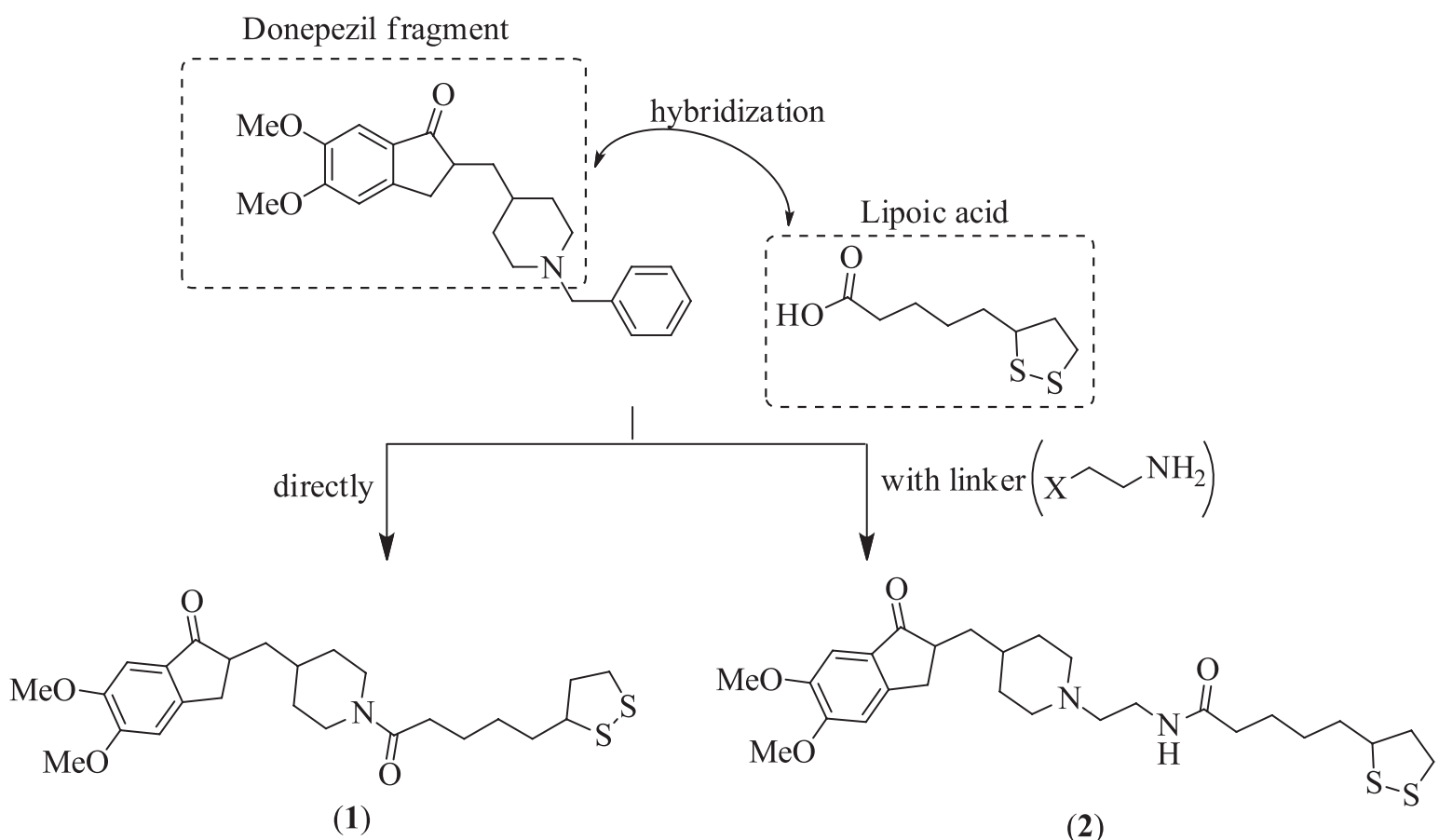

Figure 3. Design strategy for hybrids $\mathbf{1}$ and $\mathbf{2}$.

In the synthesis of hybrid $\mathbf{1}$, the first step was to obtain the indanone 4 , in high yield, by cyclization of 3-(3,4-dimethoxyphenyl)propanoic acid $\mathbf{3}$ in the presence of $p$-toluenesulfonic acid and phosphorus pentoxide $\left(\mathrm{P}_{2} \mathrm{O}_{5}\right) .{ }^{30}$ The Boc-piperidine-4-carboxaldehyde, obtained via Swern oxidation of $\mathrm{N}$-Boc-4-piperidinemethanol $\mathrm{l}^{31,32}$ was directly used in aldol condensation with $\mathbf{4}$ furnishing 5 with $84 \%$ yield $^{33}$ (Scheme 1).

In the next step, the key intermediate $\mathbf{6}$ was prepared in $91 \%$ yield by hydrogenation of the aldol adduct $\mathbf{5}$ with palladium-carbon (Pd-C) as catalyst, ${ }^{34}$ followed by removal of the Boc group under acidic aqueous media. ${ }^{35}$ Noteworthy, when the hydrogenation reaction lasted more than $20 \mathrm{~min}$, the deoxygenation product was observed. The final product 1 was obtained by coupling the amine $\mathbf{6}$ and LA using benzotriazol-1-yloxytripyrrolidinophosphonium hexafluorophosphate (PyBOP) and $N, N$-diisopropylethylamine (DIPEA) (Scheme 1). ${ }^{36}$

The synthesis of hybrid $\mathbf{2}$ featured, as first step, the protection of 2-bromoethylamine hydrobromide to afford the tert-butyl (2-bromoethyl)carbamate, ${ }^{37}$ which was reacted with 6 under basic conditions to afford the diamine 7 in 39\% yield $^{38}$ (Scheme 2). Removal of the protection group with trifluoroacetic acid (TFA) furnished $\mathbf{8}$ as trifluoroacetate salt in quantitative yield. ${ }^{39}$ Specifically, compound $\mathbf{8}$ is in the form of mono trifluoroacetate salt as confirmed by<smiles>COc1ccc(CCC(=O)O)cc1OC</smiles>

(3)<smiles>COc1cc2c(cc1OC)C(=O)CC2</smiles>

(4)<smiles>COc1cc2c(cc1OC)C(=O)/C(=C\C1CCN(C(=O)OCc3ccccc3)CC1)C2</smiles>

(5)<smiles>COc1cc2c(cc1OC)C(=O)C(CC1CCN(C(=O)CCCCC3CCSS3)CC1)C2</smiles>

(1)

Scheme 1. Synthesis of donepezil-LA hybrid 1. Reagents and conditions: (a) p-toluenesulfonic acid, $\mathrm{P}_{2} \mathrm{O}_{5}, 120{ }^{\circ} \mathrm{C}, 35$ min, $87 \%$; (b) $N$-Boc-piperidine4-carboxaldehyde, $\mathrm{NaH}$, tetrahydrofuran (THF), r.t., $2 \mathrm{~h}, 84 \%$; (c) $\mathrm{H}_{2}$ (1 atm), Pd-C (10\%), THF, r.t., 20 min, then hydrochloric acid (HCl) (3 M), ethyl acetate (EtOAc), r.t., 3 h, 91\%; (d) lipoic acid, DIPEA, PyBOP, dichloromethane (DCM), $0{ }^{\circ} \mathrm{C} \rightarrow$ r.t., 20 h, $63 \%$. 
<smiles>COc1cc2c(cc1OC)C(=O)C(CC1CCNCC1)C2</smiles>

(6)<smiles>COc1cc2c(cc1OC)C(=O)C(CC1CCN(CC[NH3+])CC1)C2</smiles>

(8)<smiles>COC(=O)NCCN1CCC(CC2Cc3cc(OC)c(OC)cc3C2=O)CC1</smiles>

(7)

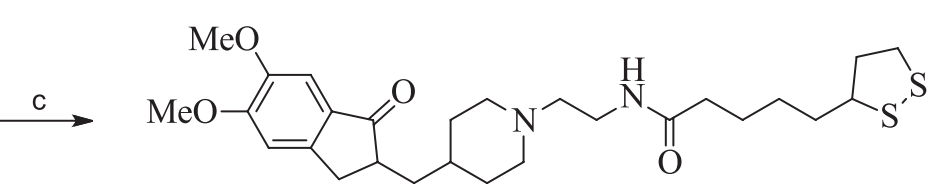

(2)

Scheme 2. Synthesis of donepezil-LA hybrid 2. Reagents and conditions: (a) tert-butyl (2-bromoethyl)carbamate, DIPEA, sodium iodide (NaI), acetonitrile $(\mathrm{MeCN})$, reflux, 24 h, 39\%; (b) TFA, DCM, r.t., 1 h, 100\%; (c) lipoic acid, DIPEA, PyBOP, DCM, $0{ }^{\circ} \mathrm{C} \rightarrow$ r.t., 20 h, $74 \%$.

HRMS analysis, which showed the mass-to-charge ratio $(\mathrm{m} / \mathrm{z})$ signals of the mono-protonated amine $\left(\mathrm{m} / \mathrm{z} \mathrm{C}_{19} \mathrm{H}_{28} \mathrm{~N}_{2} \mathrm{O}_{3}\right.$ $[\mathrm{M}+\mathrm{H}]^{+}$observed: 333.2178 ; required: 333.2166$)$. Finally, hybrid $\mathbf{2}$ was obtained by condensation of LA and $\mathbf{8}$ in the same conditions used for the synthesis of $\mathbf{1}$ (Scheme 2). ${ }^{36}$

\section{hAChE, hBChE and antioxidant assay}

Initially, to determine the potential interest of the new donepezil-LA hybrids for the treatment of $\mathrm{AD}$, the inhibitory potency toward hAChE and BuChE from human serum was assessed by Ellman's method. ${ }^{40}$ Results, expressed as half maximal inhibitory concentration $\left(\mathrm{IC}_{50}\right)$ values, i.e., the $\mathrm{IC}_{50}$ that reduces the cholinesterase activity by $50 \%$, are listed in Table 1. In particular, anti-BuChE activity has recently raised interest because it was shown that with $\mathrm{AD}$ progression, BuChE activity in specific brain regions increases while AChE activity is greatly reduced. ${ }^{41}$ Conversely to donepezil which is an AChE selective inhibitor, hybrid $\mathbf{2}$ showed to be a selective BuChE inhibitor. Hybrid $\mathbf{1}$ was scarcely soluble in the assay conditions. At the highest tested concentration $(50 \mu \mathrm{M})$ hybrid $\mathbf{1}$ did not significantly inhibit ChE enzymes.

The antioxidant activity was estimated using the DPPH antioxidant assay. ${ }^{42}$ For that purpose, different concentrations $(20-640 \mu \mathrm{M})$ of the test compounds were incubated for $30 \mathrm{~min}$ in a solution containing the stable free radical. Figure 4 shows the DPPH radical scavenging activity of new hybrids and reference compounds, expressed as percentage of scavenged DPPH radicals. All tested compounds showed a decrease in the concentration of DPPH radicals confirming their scavenging ability. Hybrid 2 was able to scavenge DPPH radicals, showing a higher activity than LA. The half maximal effective concentration $\left(\mathrm{EC}_{50}\right)$, i.e., concentration that causes $50 \%$ decrease in the DPPH radical content, was $300 \mu \mathrm{M}$. The hybrid $\mathbf{1}$ exhibited lower scavenging activity than hybrid $\mathbf{2}$, however, it was similar to that of LA. Scavenging activity of hybrid 1 and LA was not concentration dependent; similar results were obtained at all concentrations tested. The scavenging activity of LA toward DPPH radicals was $27 \%$ at $100 \mu \mathrm{M}$, in agreement with data reported in literature. ${ }^{43}$

\section{Molecular modeling}

To get insights on the binding mode, compounds $\mathbf{1}$ and 2 were docked in $\mathrm{AChE}$ and BuChE enzymes. The potential binding sites of $\mathrm{AChE}$ and $\mathrm{BuChE}$ were calculated using the built-in cavity detection algorithm from Molegro program. ${ }^{44,45}$ The BuChE enzyme has a larger cavity of $482.3 \AA^{3}$; meanwhile, AChE has a cavity of $363.0 \AA^{3}$.

Table 1. hAChE and hBuChE activities of hybrids 1, 2 and the reference compound donepezil

\begin{tabular}{lccc}
\hline Compound & $\mathrm{IC}_{50}{ }^{\mathrm{a}} \mathrm{hAChE} \pm \mathrm{SEM}^{\mathrm{b}} / \mu \mathrm{M}$ & $\mathrm{IC}_{50}{\mathrm{hBuChE} \pm \mathrm{SEM}^{\mathrm{b}} / \mu \mathrm{M}}^{\mathrm{BuChE} / \mathrm{AChE}}$ \\
\hline $\mathbf{1}$ & n.a. $^{\mathrm{c}}$ & n.a. ${ }^{\mathrm{c}}$ & - \\
$\mathbf{2}$ & $171 \pm 10$ & $62.9 \pm 5.4$ & 0.37 \\
Donepezil & $0.0203 \pm 0.0013$ & $7.13 \pm 0.19$ & 351 \\
\hline
\end{tabular}

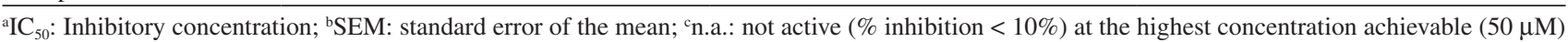
in the assay conditions. 


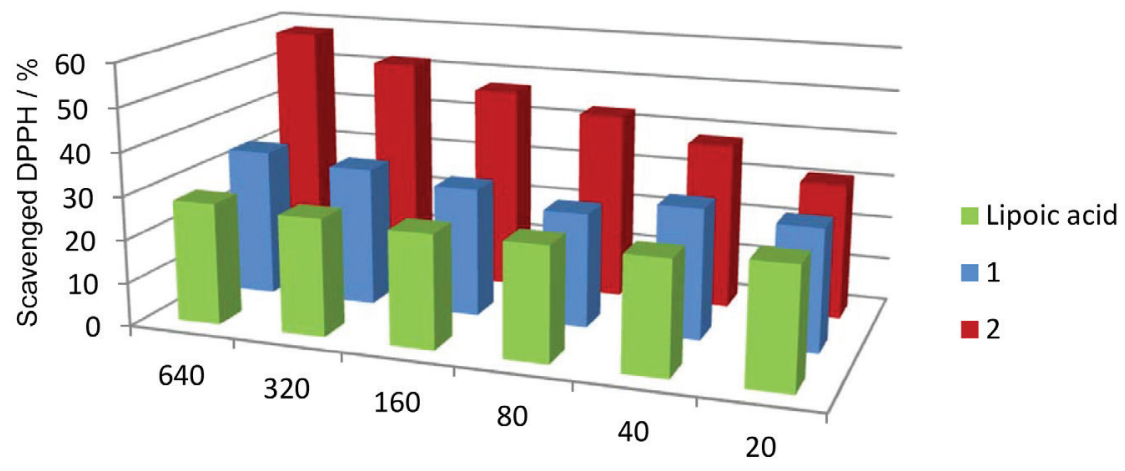

Concentration / $\mu \mathrm{M}$

Figure 4. Antioxidant activity toward DPPH radicals expressed as percentage.

Compound 2 formed a more stable protein-ligand complex with both ChEs than hybrid $\mathbf{1}$. It should be kept in mind that the interaction modes of the ligand with the active sites were determined as the lowest energy scored protein-ligand complex used during docking and the conformers of each compound were mostly associated to each other. Thus, from the theoretical findings, compound $\mathbf{2}$ revealed the lowest score energy value. For instance, differences between compound $\mathbf{2}$ and hybrid $\mathbf{1}$ of up to 10.5 and $31.8 \mathrm{kcal} \mathrm{mol}^{-1}$ were obtained for $\mathrm{AChE}$ and $\mathrm{BuChE}$, respectively.

Regarding the interaction with AChE, donepezil, 1 and 2 interacted with phenylalanine Phe295A through hydrogen
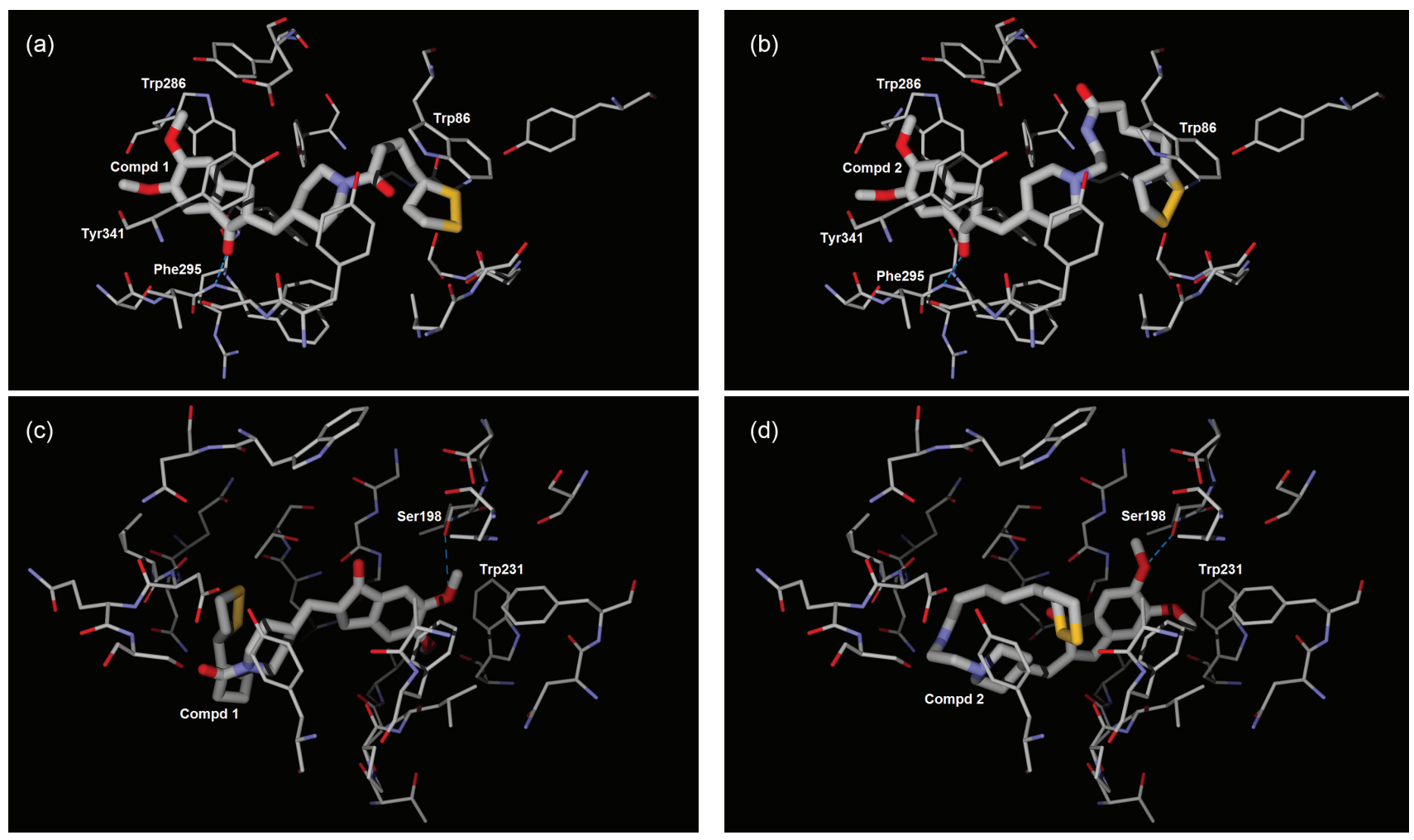

bond formation. In particular, donepezil interacted with tryptophan Trp86A (amino acid residue of catalytic site, CAS), tryptophan Trp286A and tyrosine Tyr341A (amino acid residue of peripheral anion site, PAS) through $\pi-\pi$ interactions; 1 and $\mathbf{2}$ interacted with tryptophan Trp286A and tyrosine Tyr341 through $\pi-\pi$ interaction. It is observed that the interaction with the amino acids of CAS is lost, which explains the lower activity observed of the hybrid $\mathbf{2}$ in the biological assay. Concerning BuChE, donepezil, $\mathbf{1}$ and $\mathbf{2}$ formed hydrogen bond interactions with serotonine Ser198A; furthermore, donepezil established $\pi-\pi$ interaction with tryptophan Trp231 and the methoxy group of both 1 and 2 interacted with tryptophan Trp231A (Figure 5).

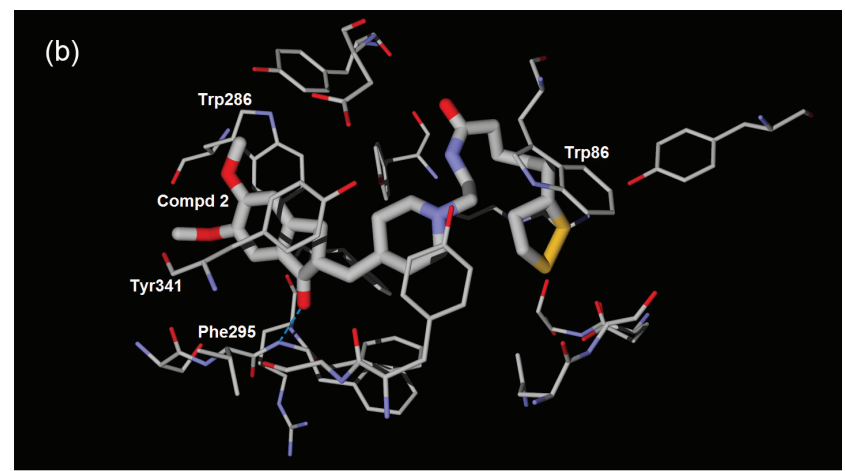

Figure 5. Docking models for (a) $\mathrm{AChE} \mathrm{(1);} \mathrm{(b)} \mathrm{AChE} \mathrm{(2);} \mathrm{(c)} \mathrm{BuChE} \mathrm{(1);} \mathrm{(d)} \mathrm{BuChE} \mathrm{(2).}$ 
It is important to note that the strength of molecular interactions was lower for compound $\mathbf{1}$ when compared to 2 , i.e., the addition of a methyl group indicated an increase of hydrophobic interactions with the residues of the hydrophobic pocket, resulting in higher binding affinity with both enzymes. This feature suggests that the inclusion of a larger linkage group between the two units can be favorable for the biological activity. Exploring the fact that in BuChE there is a larger accessible cavity to the solvent, bulky substituents as well as larger linker chains will have a greater beneficial impact on selectivity and interaction with BuChE.

The activity of hybrid $\mathbf{2}$, compared with those of benzylpiperidine hybrids reported in the literature, ${ }^{20-23}$ suggest that both interaction with the CAS and PAS of donepezil are important for the activity of this drug. When was removed from the moiety of donepezil, the inhibition of AChE enzymes was lower.

\section{Conclusions}

In this work, two donezepil-LA hybrids containing the indanone-piperidine moiety of donepezil were synthesized. Hybrid 1, in which the two fragments were connected directly, was obtained in four steps with $42 \%$ global yield, while hybrid 2, which features a linker between the two units, was synthesized in six steps, with $19 \%$ global yield. Hybrid 2 proved to be a selective BuChE inhibitor even if less potent than donepezil and a good antioxidant agent. In particular, the lower activity can be ascribed to the loss of the interaction with Trp86A, an amino acid of the AChE CAS, when the benzyl moiety of donepezil is replaced by LA. The selectivity of $\mathbf{2}$ toward hBuChE is explained by the larger gorge of this enzyme, which can better accommodate hybrid 2 . Finally, and quite interestingly, hybrid 2 showed better scavenging ability toward DPPH radicals than LA. The combined anti-ChE and antioxidant properties exhibited by the hybrid $\mathbf{2}$ confirm their potential as anti-AD agents.

\section{Experimental}

\section{General techniques}

All starting materials were obtained from commercially available sources with high-grade purity and used without further purification. Proton nuclear magnetic resonance $\left({ }^{1} \mathrm{H}\right.$ NMR) and carbon-13 $\left({ }^{13} \mathrm{C}\right) \mathrm{NMR}$ spectra at 200 and $400 \mathrm{MHz}$ were obtained on a Bruker AVANCE DPX 200 and a Bruker AVANCE DRX 400 spectrometer, respectively. The chemical shifts $(\delta)$ are expressed in parts per million (ppm) and are referenced to signals from tetramethylsilane (TMS) or residual solvent signal. ${ }^{1} \mathrm{H}$ NMR data are presented in the following order: chemical shift in ppm (multiplicity, coupling constant $(J)$ in hertz $(\mathrm{Hz})$, integration). Melting points (mp) (uncorrected) were obtained on a Mettler FP 80 HT apparatus. Infrared spectra were recorded on a PerkinElmer Spectrum One spectrometer. The high resolution mass spectra were obtained using a mass spectrometer with an electrospray ionization source (ESI-MS) model Shimadzu LC-ITTOF.

\section{Synthesis}

\section{5,6-Dimethoxy-2,3-dihydro-1 $H$-inden-1-one (4)}

In a round bottom flask, $\mathrm{P}_{2} \mathrm{O}_{5}(6.85 \mathrm{~g}, 36 \mathrm{mmol})$ and toluenesulfonic acid $(5.11 \mathrm{~g}, 36 \mathrm{mmol})$ was warmed to $120{ }^{\circ} \mathrm{C}$ and stirred for $30 \mathrm{~min}$. To the clear homogeneous solution was added the 3-(3,4-dimethoxyphenyl)propanoic acid $(0.630 \mathrm{~g}, 3.0 \mathrm{mmol})$ in one portion and the solution was stirred at $120{ }^{\circ} \mathrm{C}$ for $5 \mathrm{~min}$. Then, ice water was added to the deep purple solution formed and the resulting mixture was extracted three times with dichloromethane $\left(\mathrm{CH}_{2} \mathrm{Cl}_{2}\right)$. The combined organic layers were washed with saturated solution of sodium bicarbonate $\left(\mathrm{NaHCO}_{3}\right)$, dried with magnesium sulfate $\left(\mathrm{MgSO}_{4}\right)$, filtered and concentrated under reduced pressure. The resulting brown solid was purified by chromatography column eluted with ethylacetate/hexane (1:1, v:v) yielding 4 as a yellow solid $(0.51 \mathrm{~g})$ in $87 \%$ yield; $\mathrm{mp} 118-119^{\circ} \mathrm{C}\left(\mathrm{Lit}^{46} 116-118^{\circ} \mathrm{C}\right)$; IR (attenuated total reflection (ATR)) $\mathrm{v} / \mathrm{cm}^{-1} 3001,2923$, 2853, 1688, 1604, 1590, 1500, 1457, 1440, 1423, 1364, 1309, 1264, 1245, 1211, 1188, 1175, 1156, 1118, 1074, 1038, 985, 962, 847, 816, 780, 710; ${ }^{1} \mathrm{H}$ NMR (400 MHz, $\left.\mathrm{CDCl}_{3}\right) \delta 2.56-2.59(\mathrm{~m}, 2 \mathrm{H}), 2.96\left(\mathrm{t}, 2 \mathrm{H},{ }^{3} \mathrm{~J}=5.6 \mathrm{~Hz}\right), 3.82$ $(\mathrm{s}, 3 \mathrm{H}), 3.88(\mathrm{~s}, 3 \mathrm{H}), 6.81(\mathrm{~s}, 1 \mathrm{H}), 7.08(\mathrm{~s}, 1 \mathrm{H}) ;{ }^{13} \mathrm{C} \mathrm{NMR}$ $\left(100 \mathrm{MHz}, \mathrm{CDCl}_{3}\right) \delta 25.6,36.6,56.3,56.1,104.3,107.6$, 130.0, 149.5, 150.5, 155.5, 205.7; HRMS (ESI) $\mathrm{m} / \mathrm{z}$, observed: 193.0863 for $\mathrm{C}_{11} \mathrm{H}_{12} \mathrm{O}_{3}[\mathrm{M}+\mathrm{H}]^{+}$; required: 193.0864 .

(E)-tert-Butyl 4-((5,6-dimethoxy-1-oxo-1H-inden2(3H)-ylidene)methyl)piperidine-1-carboxylate (5)

Under argon atmosphere, a solution of oxalylchloride (0.2 mL, $2.2 \mathrm{mmol})$ in anhydrous $\mathrm{CH}_{2} \mathrm{Cl}_{2}(5 \mathrm{~mL})$ was cooled to $-78{ }^{\circ} \mathrm{C}$ and a solution of dimethyl sulfoxide (DMSO) $(0.31 \mathrm{~mL}, 4.4 \mathrm{mmol})$ in anhydrous $\mathrm{CH}_{2} \mathrm{Cl}_{2}$ (1 mL) was dropwise added. After stirring for $10 \mathrm{~min}$, a solution of $\mathrm{N}$-Boc-4-piperidinemethanol (0.43 g, $2 \mathrm{mmol}$ ) in anhydrous $\mathrm{CH}_{2} \mathrm{Cl}_{2}(1 \mathrm{~mL})$ was added. Triethylamine (1.4 $\mathrm{mL}, 10.2 \mathrm{mmol}$ ) was added after $15 \mathrm{~min}$ and the reaction was allowed to warm up to room temperature. The 
reaction was quenched by the addition of water $(10 \mathrm{~mL})$ after $2 \mathrm{~h}$ and the mixture extracted four times with $\mathrm{CH}_{2} \mathrm{Cl}_{2}$. The combined organic layers were dried with $\mathrm{MgSO}_{4}$, filtered and concentrated under reduced pressure. The crude aldehyde was used in the next step without further purification.

To a solution of 5,6-dimethoxy-indanone (4) $(0.19 \mathrm{~g}, 1 \mathrm{mmol})$ in anhydrous THF $(5 \mathrm{~mL})$ was added sodium hydride $(\mathrm{NaH})(0.05 \mathrm{~g}, 1.2 \mathrm{mmol}, 60 \%$ dispersion in mineral oil). After stirring for $30 \mathrm{~min}$, a solution of crude aldehyde in THF $(1 \mathrm{~mL})$ was added dropwise, and the resulting mixture was stirred at room temperature for $2 \mathrm{~h}$. The solvent was concentrated under reduced pressure, and to the residual product was added water and extracted three times with $\mathrm{CH}_{2} \mathrm{Cl}_{2}$. The combined organic layers were dried with $\mathrm{MgSO}_{4}$, filtered and concentrated under reduced pressure. The crude reaction was purified by chromatography column eluted ethyl acetate/hexane $(1: 1, \mathrm{v}: \mathrm{v})$ yielding 5 as oil $(0.32 \mathrm{~g})$ in $84 \%$ yield; IR (ATR) $v / \mathrm{cm}^{-1} 3403,2926,2850,2732,1682,1605,1590,1500$, $1463,1316,1265,1218,1120,1040,1004,975,862,789$; ${ }^{1} \mathrm{H}$ NMR $\left(400 \mathrm{MHz}, \mathrm{CDCl}_{3}\right) \delta 1.48(\mathrm{~s}, 11 \mathrm{H}), 1.69-1.72$ (m, 2H), 2.44-2.53 (m, 1H), 2.80-2,86 (m, 2H), 3.62 (s, $2 \mathrm{H})$, $3.93(\mathrm{~s}, 3 \mathrm{H}), 3.98(\mathrm{~s}, 3 \mathrm{H}), 4.12-4.15(\mathrm{~m}, 2 \mathrm{H}), 6.62(\mathrm{~d}, 1 \mathrm{H}$, $J=12 \mathrm{~Hz}), 6.91(\mathrm{~s}, 1 \mathrm{H}), 7.30(\mathrm{~s}, 1 \mathrm{H}) ;{ }^{13} \mathrm{C}$ NMR $(100 \mathrm{MHz}$, $\left.\mathrm{CDCl}_{3}\right) \delta 28.8,29.8,31.2,37.6,43.6,56.5,56.6,79.9$, 105.4, 107.6, 132.1, 136.3, 138.8, 144.7, 149.9, 155.1, 155.8, 192.8; HRMS (ESI) $\mathrm{m} / z$, observed: 410.1931 for $\mathrm{C}_{22} \mathrm{H}_{29} \mathrm{NO}_{5}[\mathrm{M}+\mathrm{Na}]^{+}$; required: 410.1944 .

5,6-Dimethoxy-2-(piperidin-4-ylmethyl)-2,3-dihydro$1 \mathrm{H}$-inden-1-one $(\mathbf{6})$

To a solution of $5(0.22 \mathrm{~g}, 0.57 \mathrm{mmol})$ in THF $(5 \mathrm{~mL})$ the Pd-C (0.01 g, 10\% Pd-C) was added. The reaction mixture was purged with hydrogen and stirred at room temperature under hydrogen atmosphere for $20 \mathrm{~min}$. Then, the reaction was filtered through celite washing with methanol and the solvent was removed under reduced pressure. The crude product $(0.20 \mathrm{~g})$ was solubilized in ethyl acetate $(10 \mathrm{~mL})$ and $\mathrm{HCl} 3 \mathrm{M}(8 \mathrm{~mL})$ was added. The reaction mixture was stirred at room temperature for $3 \mathrm{~h}$. After this time, the solvent was concentrated under reduced pressure and the residue was dissolved with saturated $\mathrm{NaHCO}_{3}$ solution. The resulting solution was extracted three times with $\mathrm{CH}_{2} \mathrm{Cl}_{2}$. The organic phases were dried over anhydrous $\mathrm{MgSO}_{4}$ and concentrated under reduced pressure yielding the desired product (6) in 91\% yield; IR (ATR) $v / \mathrm{cm}^{-1} 3403,2926,2850,2732,1682,1605,1590,1500$, $1463,1316,1265,1218,1120,1040,1004,975,862,789$; ${ }^{1} \mathrm{H}$ NMR $\left(400 \mathrm{MHz}, \mathrm{CDCl}_{3}\right) \delta 1.25-1.39(\mathrm{~m}, 3 \mathrm{H}), 1.70-1.82$ $(\mathrm{m}, 3 \mathrm{H}), 1.89-1.95(\mathrm{~m}, 1 \mathrm{H}), 2.55(\mathrm{sl}, 2 \mathrm{H}), 2.69-2.73$ (m, 4H), 3.20-3.29 (m, 2H), 3.91 (s, 3H), 3.97 (s, 3H), 6.86 (s, 1H), 7.17 (s, 1H); HRMS (ESI) $\mathrm{m} / z$, observed: 290.1761 for $\mathrm{C}_{17} \mathrm{H}_{23} \mathrm{NO}_{3}[\mathrm{M}+\mathrm{H}]^{+}$; required: 290.1756 .

2-((1-(5-(1,2-Dithiolan-3-yl)pentanoyl)piperidin-4-yl)methyl)5,6-dimethoxy-2,3-dihydro-1 $H$-inden-1-one (1)

A solution of lipoic acid $(0.06 \mathrm{~g}, 0.25 \mathrm{mmol})$ and PyBOP $(0.13 \mathrm{~g}, 0.25 \mathrm{mmol})$, in anhydrous $\mathrm{CH}_{2} \mathrm{Cl}_{2}$ $(4.5 \mathrm{~mL})$, at $0{ }^{\circ} \mathrm{C}$, was stirred for $30 \mathrm{~min}$ and then, cannulated to a flask containing a solution of (6) $(0.1 \mathrm{~g}, 0.27 \mathrm{mmol}), N, N$-diisopropylethylamine $(0.25 \mathrm{~g}, 1.97 \mathrm{mmol})$, in anhydrous $\mathrm{CH}_{2} \mathrm{Cl}_{2}(4.5 \mathrm{~mL})$. The resulting mixture was stirred at room temperature for $20 \mathrm{~h}$. Then, the reaction was quenched by the addition of water and the mixture was extracted four times with $\mathrm{CH}_{2} \mathrm{Cl}_{2}$. The combined organic layers were dried with $\mathrm{MgSO}_{4}$, filtered and concentrated under reduced pressure. The crude reaction was purified by chromatography column eluted with ethyl acetate/methanol (5\%) yielding $\mathbf{1}$ as a beige solid $(0.07 \mathrm{~g})$ in $63 \%$ yield; IR (ATR) $\mathrm{v} / \mathrm{cm}^{-1} 2924,2848$, 1691, 1630, 1607, 1591, 1499, 1452, 1437, 1363, 1341, $1312,1263,1224,1213,1153,1121,1072,1036,968$, 861, 840, 792, 765, 730, 700; ' $\mathrm{H}$ NMR $(400 \mathrm{MHz}$, $\left.\mathrm{CDCl}_{3}\right) \delta$ 1.23-1.29 (m, 3H), 1.38-1.44 (m, 2H), 1.49$1.56(\mathrm{~m}, 2 \mathrm{H}), 1.64-1.77(\mathrm{~m}, 4 \mathrm{H}), 1.86-1.95(\mathrm{~m}, 5 \mathrm{H})$, 2.44-2.53 (m, 3H), 2.70-2.71 (m, $2 \mathrm{H}), 3.09-3.22(\mathrm{~m}, 3 \mathrm{H})$, 3.28 (dd, $1 \mathrm{H}, J=20,8 \mathrm{~Hz}$ ), 3.60 (qui, $1 \mathrm{H}, J=8 \mathrm{~Hz}$ ), 3.91 (s, 3H), 3.97 (s, 3H), $6.88(\mathrm{~s}, 1 \mathrm{H}), 7.16(\mathrm{~s}, 1 \mathrm{H}) ;{ }^{13} \mathrm{C} \mathrm{NMR}$ $\left(100 \mathrm{MHz}, \mathrm{CDCl}_{3}\right) \delta 25.6\left(\mathrm{CH}_{2}\right), 29.2\left(\mathrm{CH}_{2}\right), 32.5$ $\left(\mathrm{CH}_{2}\right), 33.6\left(\mathrm{CH}_{2}\right), 34.4(\mathrm{CH}), 34.7\left(\mathrm{CH}_{2}\right), 38.6\left(\mathrm{CH}_{2}\right)$, $38.7\left(\mathrm{CH}_{2}\right), 40.5\left(\mathrm{CH}_{2}\right), 45.2(\mathrm{CH}), 56.3\left(\mathrm{OCH}_{3}\right), 56.4$ $\left(\mathrm{OCH}_{3}\right), 56.6(\mathrm{CH}), 104.7\left(\mathrm{C}_{\mathrm{Ar}}\right), 107.6\left(\mathrm{C}_{\mathrm{Ar}}\right), 129.3\left(\mathrm{C}_{\mathrm{Ar}}\right)$, 148.8 $\left(\mathrm{C}_{\mathrm{Ar}}\right), 149.8\left(\mathrm{C}_{\mathrm{Ar}}\right), 155.9\left(\mathrm{C}_{\mathrm{Ar}}\right), 172.9(\mathrm{~N} \underline{\mathrm{C}}=\mathrm{O})$, $207.3(\underline{\mathrm{C}}=\mathrm{O}$ ); HRMS (ESI) $\mathrm{m} / \mathrm{z}$, observed: 500.1859 for $\mathrm{C}_{25} \mathrm{H}_{35} \mathrm{NO}_{4} \mathrm{~S}_{2}[\mathrm{M}+\mathrm{Na}]^{+}$; required: 500.1905.

tert-Butyl(2-(4-((5,6-dimethoxy-1-oxo-2,3-dihydro-1 $H$-inden2-yl)methyl)piperidin-1-yl)ethyl)carbamate (7)

A solution of compound $6(0.20 \mathrm{~g}, 0.61 \mathrm{mmol})$, $\mathrm{NaI}(0.09 \mathrm{~g}, 0.61 \mathrm{mmol})$ and $N, N$-diisopropylethylamine $(0.16 \mathrm{~g}, 1.22 \mathrm{mmol})$ in acetonitrile $(12 \mathrm{~mL})$ was dropwise added to a solution of tert-butyl (2-bromoethyl)carbamate $(0.18 \mathrm{~g}, 0.79 \mathrm{mmol})$ in acetonitrile $(1 \mathrm{~mL})$. Then, the reaction was heated to reflux temperature and kept under stirring for $24 \mathrm{~h}$. After that time, a reaction mixture was concentrated under reduced pressure and the residue was solubilized in ethyl acetate and washed with solution of potassium carbonate $\left(\mathrm{K}_{2} \mathrm{CO}_{3}\right) 1 \mathrm{M}$. The organic phase was extracted with two portions of ethyl acetate. The organic phase was then dried over anhydrous $\mathrm{MgSO}_{4}$ and 
concentrated under reduced pressure on a rotary evaporator. The crude reaction was purified by chromatography column eluted with ethyl acetate/methanol (4:1, v:v) and the desired product 7 was obtained in $39 \%(0.10 \mathrm{~g})$; IR (ATR) $\mathrm{v} / \mathrm{cm}^{-1}$ 3426, 2920, 2852, 1692, 1626, 1468, 1364, 1316, 1256, 1170, 1118, 1042; ${ }^{1} \mathrm{H}$ NMR (400 MHz, $\left.\mathrm{CDCl}_{3}\right) \delta 1.14-1.41$ $(\mathrm{m}, 6 \mathrm{H}), 1.46(\mathrm{~s}, 9 \mathrm{H}), 1.62-1.81(\mathrm{~m}, 4 \mathrm{H}), 1.88-1.94$ (m, 1H), 2.68-2.76 (m, 4H), $3.25(\mathrm{dd}, 1 \mathrm{H}, J=20,8 \mathrm{~Hz})$, 3.91 (s, 3H), 3.96 (s, 3H), 4.08-4.13 (m, 2H), 6.86 (s, 1H), $7.17(\mathrm{~s}, 1 \mathrm{H}) ;{ }^{13} \mathrm{C} \mathrm{NMR}\left(100 \mathrm{MHz}, \mathrm{CDCl}_{3}\right) \delta 28.7,32.0$, 33.0, 33.6, 34.8, 38.9, 44.2, 45.4, 56.3, 56.4, 79.5, 104.7, 107.6, 129.5, 148.8, 149.8, 155.1, 155.8, 207.7; HRMS (ESI) $m / z$, observed: 433.2684 for $\mathrm{C}_{24} \mathrm{H}_{36} \mathrm{~N}_{2} \mathrm{O}_{5}[\mathrm{M}+\mathrm{H}]^{+}$; required: 432.2624 .

1-(2-Aminoethyl)-4-((5,6-dimethoxy-1-oxo-2,3-dihydro$1 H$-inden-2-yl)methyl)piperidin-1-ium 2,2,2-trifluoroacetate (8)

Trifluoroacetic acid $(1.2 \mathrm{~mL})$ was added to a solution of $7(0.08 \mathrm{~g}, 0.18 \mathrm{mmol})$ in $\mathrm{CH}_{2} \mathrm{Cl}_{2}(1.2 \mathrm{~mL})$ under ice bath. The reaction was stirred for $1 \mathrm{~h}$. After this period, the reaction mixture was concentrated under reduced pressure and the desired product $\mathbf{8}$ was obtained in quantitative yield. IR (ATR) $v / \mathrm{cm}^{-1}$ 3422, 2958, 2922, 2872, 2852, 1690, $1610,1500,1458,1318,1268,1204,1128,1036 ;{ }^{1} \mathrm{H}$ NMR (400 MHz, $\left.\mathrm{CD}_{3} \mathrm{OD}\right) \delta$ 1.35-1.36 (m, 1H), 1.47-1.57 (m, $1 \mathrm{H}), 1.65-1.74(\mathrm{~m}, 2 \mathrm{H}), 1.92-2.01(\mathrm{~m}, 2 \mathrm{H}), 2.11-2.21(\mathrm{~m}$, 2H), 2.79-2.83 (m, 2H), 3.18 (sl, 2H), 3.52 (sl, 4H) 3.70 (sl, 2H), 3.92 (s, 3H), $4.00(\mathrm{~s}, 3 \mathrm{H}), 7.12(\mathrm{~s}, 1 \mathrm{H}), 7.21(\mathrm{~s}$, 1H), 7.94-7.95 (m, 1H, NH); ${ }^{13} \mathrm{C} \mathrm{NMR}\left(100 \mathrm{MHz}, \mathrm{CD}_{3} \mathrm{OD}\right)$ $\delta 19.5,30.9,33.2,34.3,39.0,46.3,54.6,54.9,56.6,56.9$, $105.5,109.2$, 129.9, 151.3, 151.5, 157.9, 209.9; HRMS (ESI) $m / z$, observed: 333.2166 for $\mathrm{C}_{19} \mathrm{H}_{28} \mathrm{~N}_{2} \mathrm{O}_{3}[\mathrm{M}+\mathrm{H}]^{+}$; required: 333.2178 .

$\mathrm{N}$-(2-(4-((5,6-Dimethoxy-1-oxo-2,3-dihydro-1 $\mathrm{H}$-inden2-yl)methyl)piperidin-1-yl)ethyl)-5-(1,2-dithiolan-3-yl) pentanamide (2)

A solution of lipoic acid $(0.05 \mathrm{~g}, 0.22 \mathrm{mmol})$ and PyBOP $(0.11 \mathrm{~g}, 0.22 \mathrm{mmol})$, in anhydrous $\mathrm{CH}_{2} \mathrm{Cl}_{2}$ $(3.5 \mathrm{~mL})$, at $0{ }^{\circ} \mathrm{C}$, was stirred for $30 \mathrm{~min}$ and then cannulated to a flask containing a solution of $\mathbf{8}(0.11 \mathrm{~g}, 0.24$ $\mathrm{mmol}), N, N$-diisopropylethylamine $(0.23 \mathrm{~g}, 1.76 \mathrm{mmol})$, in anhydrous $\mathrm{CH}_{2} \mathrm{Cl}_{2}(4 \mathrm{~mL})$ and the resulting mixture was stirred at room temperature for $20 \mathrm{~h}$. Then, the reaction was quenched by the addition of water and the mixture was extracted four times with $\mathrm{CH}_{2} \mathrm{Cl}_{2}$. The combined organic layers were dried with $\mathrm{MgSO}_{4}$, filtered and concentrated under reduced pressure. The crude reaction was purified by chromatography column eluted with ethyl acetate/methanol (10\%) yielding 2 as oil (0.08 g) in
74\% yield; IR (ATR) v / cm $\mathrm{cm}^{-1} 3383,3279,3071,2926,2853$, 2641, 2548, 2363, 1739, 1727, 1687, 1606, 1591, 1562, $1548,1542,1536,1500,1456,1439,1365,1316,1266$, 1223, 1191, 1160, 1121, 1088, 1077, 1066, 1037, 1008, 972, 952, 862, 848, 797, 765, 750; ${ }^{1} \mathrm{H}$ NMR (400 MHz, $\left.\mathrm{CDCl}_{3}\right) \delta 1.40-1.52(\mathrm{~m}, 3 \mathrm{H}), 1.63-1.76(\mathrm{~m}, 7 \mathrm{H}), 1.83-1.96$ (m, 4H), $2.26(\mathrm{t}, 2 \mathrm{H}, J=8 \mathrm{~Hz}), 2.32-2.40(\mathrm{~m}, 2 \mathrm{H}), 2.46$ $\left(\mathrm{td}, 1 \mathrm{H},{ }^{2} J=16 \mathrm{~Hz},{ }^{3} \mathrm{~J}=8 \mathrm{~Hz}\right), 2.67-2.71(\mathrm{~m}, 2 \mathrm{H}), 2.77$ $(\mathrm{t}, 2 \mathrm{H}, J=5 \mathrm{~Hz}), 3.08-3.21(\mathrm{~m}, 4 \mathrm{H}), 3.28(\mathrm{dd}, 1 \mathrm{H}, J=20$, $8 \mathrm{~Hz}$ ), 3.50 (q, $2 \mathrm{H}, J=5 \mathrm{~Hz}$ ), 3.58 (qui, $1 \mathrm{H}, J=8 \mathrm{~Hz}$ ), $3.91(\mathrm{~s}, 3 \mathrm{H}), 3.97$ (s, 3H), $6.86(\mathrm{~s}, 1 \mathrm{H}), 7.05$ (sl, 1H, NH), $7.16(\mathrm{~s}, 1 \mathrm{H}) ;{ }^{13} \mathrm{C} \mathrm{NMR}\left(100 \mathrm{MHz}, \mathrm{CDCl}_{3}\right) \delta 25.4\left(\mathrm{CH}_{2}\right)$, $29.0\left(\mathrm{CH}_{2}\right), 29.8\left(\mathrm{CH}_{2}\right), 30.0\left(\mathrm{CH}_{2}\right), 32.7(\mathrm{CH}), 33.8\left(\mathrm{CH}_{2}\right)$, $34.7\left(\mathrm{CH}_{2}\right), 36.3\left(\mathrm{CH}_{2}\right), 38.1\left(\mathrm{CH}_{2}\right), 38.6\left(\mathrm{CH}_{2}\right), 40.4$ $\left(\mathrm{CH}_{2}\right), 44.8(\mathrm{CH}), 53.7\left(\mathrm{CH}_{2}\right), 56.3\left(\mathrm{CH}_{3}\right), 56.4\left(\mathrm{CH}_{3}\right)$, $56.7(\mathrm{CH}), 57.5\left(\mathrm{CH}_{2}\right), 104.6(\mathrm{CH}), 107.6\left(\mathrm{CH}_{2}\right), 129.2$ $\left(\mathrm{C}_{\mathrm{Ar}}\right), 148.8\left(\mathrm{C}_{\mathrm{Ar}}\right), 149.8\left(\mathrm{C}_{\mathrm{Ar}}\right), 155.9\left(\mathrm{C}_{\mathrm{Ar}}\right), 173.8(\mathrm{NC}=\mathrm{O})$, $207.2(\mathrm{C}=\mathrm{O}$ ); HRMS (ESI) $\mathrm{m} / z$, observed: 521.2452 for $\mathrm{C}_{27} \mathrm{H}_{40} \mathrm{~N}_{2} \mathrm{O}_{4} \mathrm{~S}_{2}[\mathrm{M}+\mathrm{H}]^{+}$; required: 521.2507.

Determination of inhibitory effect on AChE and BuChE activity

The capacity of compound $\mathbf{2}$ and donepezil to inhibit AChE activity was assessed using the Ellman method. ${ }^{40}$ Initial rate assays were performed at $37{ }^{\circ} \mathrm{C}$ with a Jasco V-530 double beam spectrophotometer by following the rate of increase in the absorbance at $412 \mathrm{~nm}$ for $3 \mathrm{~min}$. AChE stock solution was prepared by dissolving human recombinant AChE (E.C.3.1.1.7) lyophilized powder (Sigma, Italy) in $0.1 \mathrm{M}$ phosphate buffer ( $\mathrm{pH}=8.0$ ) containing Triton X-100 (0.1\% v:v). Stock solution of BuChE (E.C. 3.1.1.8) from human serum (Sigma, Italy) was prepared by dissolving the lyophilized powder in an aqueous solution of gelatine $(0.1 \% \mathrm{~m}: \mathrm{v})$. The final assay solution consisted of a $0.1 \mathrm{M}$ phosphate buffer $\mathrm{pH} 8.0$, with the addition of $340 \mu \mathrm{M}$ 5,5'-dithio-bis(2-nitrobenzoic acid), 0.02 unit $\mathrm{mL}^{-1}$ of human recombinant $\mathrm{AChE}$, or BuChE from human serum and $550 \mu \mathrm{M}$ of substrate (acetylthiocholine iodide, ATCh or butyrylthiocholine iodide, BTCh, respectively). Stock solutions of $\mathbf{2}$ were prepared in methanol and diluted in methanol, while donepezil was solubilized in water and dilutions were prepared in water. Five different concentrations of inhibitor were selected in order to obtain inhibition of the enzymatic activity comprised between 20 and $80 \% .50 \mu \mathrm{L}$ aliquots of increasing concentration of inhibitor were added to the assay solution and pre incubated for $20 \mathrm{~min}$ at $37^{\circ} \mathrm{C}$ with the enzyme before the addition of the substrate. Assays were carried out with a blank containing all components except AChE or BuChE 
in order to account for the non-enzymatic reaction. The reaction rates were compared and the percent inhibition due to the presence of inhibitor was calculated. Each concentration was analysed in duplicate, and $\mathrm{IC}_{50}$ values were determined graphically from log concentration versus \% inhibition curves (GraphPad Prism 4.03 software, GraphPad Software Inc.). ${ }^{47}$

\section{Scavenging of DPPH radicals}

The ability of hybrids to scavenge DPPH radical, a reactive nitrogen species (RNS), was determined according to Gülçin ${ }^{48}$ with modifications. The screening was done by incubating $50 \mu \mathrm{L}$ of each compound in an ethanolic medium containing $50 \mu \mathrm{L}$ of $200 \mu \mathrm{M}$ DPPH. Final concentrations of test compounds were between $20-640 \mu \mathrm{M}$ and the DPPH was $100 \mu \mathrm{M}$. The systems were maintained under stirring in the dark for $30 \mathrm{~min}$. The absorbance at $517 \mathrm{~nm}$ was recorded. Each concentration was tested in triplicate.

\section{Theoretical calculations}

Crystal coordinates of the human $\mathrm{AChE}$ and BuChE enzymes were downloaded from Protein Data Bank (PDB code: 4BDT ${ }^{49}$ and $5 \mathrm{LKR},{ }^{50}$ respectively). Donepezil, 1 and 2 (Figure 3) were docked into both binding sites using the Molegro Virtual Docker (MVD), ${ }^{44,45}$ a program for predicting the most likely conformation of how a ligand will bind to a macromolecule. MolDock scoring funcion (MolDock Score) employed by the MVD program is regulated on a new hybrid search algorithm, called guided differential evolution. This algorithm combines the differential evolution optimization technique with a cavity prediction algorithm during the searching procedure, which allows a fast and accurate recognition of binding modes. It is derived from the piecewise linear potential (PLP), a simplified potential whose parameters are fit to proteinligand structures and binding data scoring functions ${ }^{44}$ and further extended in GEMDOCK program ${ }^{51}$ (generic evolutionary method for molecular DOCK) with a new hydrogen bonding term and new charge schemes. Only ligand molecules are considered flexible during the docking simulation. Thus, a candidate solution is encoded by an array of real-valued numbers representing ligand position, orientation, and conformation as Cartesian coordinates for the ligand translation, four variables specifying the ligand orientation (encoded as a rotation vector and a rotation angle), and one angle for each flexible torsion angle in the ligand.

\section{Supplementary Information}

Copies of ${ }^{1} \mathrm{H}$ and ${ }^{13} \mathrm{C}$ NMR spectra of synthesized compounds are available free of charge at http://jbcs.sbq.org.br as PDF file.

\section{Acknowledgments}

This research was carried out in the framework of $\mathrm{B}^{2} \mathrm{AlzD}^{2}$ Joint lab. Financial support was obtained from the Coordenação de Aperfeiçoamento de Pessoal de Nível Superior (CAPES), Fundação de Amparo à Pesquisa do Estado de Minas Gerais (FAPEMIG), Conselho Nacional de Desenvolvimento Científico e Tecnológico (CNPq) and from the Italian Ministry of Education, Universities and Research (MIUR). Dr Christian Bergamini and Prof Romana Fato from Alma Mater Studiorum University of Bologna are acknowledged for their contribution to the characterization of the activity profile of the new hybrids.

\section{References}

1. Chiatti, C.; Furneri, G.; Rimland, J. M.; Demma, F.; Bonfranceschi, F.; Cassetta, L.; Masera, F.; Cherubini, A.; Corsonello, A.; Lattanzio, F.; Int. Psychogeriatr. 2015, 27, 1563.

2. McGleenon, B. M.; Dynan, K. B.; Passmore, A. P.; Br. J. Clin. Pharmacol. 1999, 48, 471.

3. Bolognesi, M. L.; Matera, R.; Minarini, A.; Rosini, M.; Melchiorre, C.; Curr. Opin. Chem. Biol. 2009, 13, 303.

4. Bolognesi, M. L.; Cavalli, A.; Valgimigli, L.; Bartolini, M.; Rosini, M.; Andrisano, V.; Recanatini, M.; Melchiorre, C.; J. Med. Chem. 2007, 50, 6446.

5. Pratico, D.; Neurobiol. Aging 2005, 26, 581.

6. Garibotto, V.; Tettamanti, M.; Marcone, A.; Florea, I.; Panzacchi, A.; Moresco, R.; Virta, J. R.; Rinne, J.; Cappa, S. F.; Perani, D.; Neurobiol. Aging 2013, 34, 2694.e13.

7. Bartus, R. T.; Dean, R. L.; Beer, B.; Lippa, A. S.; Science 1982, 217,408 .

8. Heinrich, M.; Teoh, H. L.; J. Ethnopharmacol. 2004, 92, 147.

9. Gibson, G. E.; Free Radical Biol. Med. 2002, 32, 1061.

10. Behl, C.; Moosmann, B.; Free Radical Biol. Med. 2002, 33, 182.

11. Cavalli, A.; Bolognesi, M. L.; Minarini, A.; Rosini, M.; Tumiatti, V.; Recanatini, M.; Melchiorre, C.; J. Med. Chem. 2008, 51, 347.

12. Bolognesi, M. L.; Curr. Med. Chem. 2013, 20, 1639.

13. Simoes, M. C. R.; Viegas, F. P. D.; Moreira, M. S.; Silva, M. F.; Riquiel, M. M.; da Rosa, P. M.; Castelli, M. R.; dos Santos, M. H.; Soares, M. G.; Viegas Junior, C.; Mini-Rev. Med. Chem. 2014, 14, 2. 
14. Ismaili, L.; Refouvelet, B.; Benchekroun, M.; Brogi, S.; Brindisi, M.; Gemma, S.; Campiani, G.; Filipic, S.; Agbaba, D.; Esteban, G.; Unzeta, M.; Nikolic, K.; Butini, S.; MarcoContelles, J.; Prog. Neurobiol. 2017, 151, 4.

15. Alonso, D.; Dorronsoro, I.; Rubio, L.; Muñoz, P.; GarcíaPalomero, E.; Del Monte, M.; Bidon-Chanal, A.; Orozco, M.; Luque, F. J.; Castro, A.; Medina, M.; Martínez, A.; Bioorg. Med. Chem. 2005, 13, 6588.

16. Camps, P.; Formosa, X.; Galdeano, C.; Gomez, T.; MunozTorrero, D.; Scarpellini, M.; Viayna, E.; Badia, A.; Clos, M. V.; Camins, A.; Pallas, M.; Bartolini, M.; Mancini, F.; Andrisano, V.; Estelrich, J.; Lizondo, M.; Bidon-Chanal, A.; Luque, F. J.; J. Med. Chem. 2008, 51, 3588.

17. Zhu, Y.; Xiao, K.; Ma, L.; Xiong, B.; Fu, Y.; Yu, H.; Wang, W.; Wang, X.; Hu, D.; Peng, H.; Li, J.; Gong, Q.; Chai, Q.; Tang, X.; Zhang, H.; Shen, J.; Bioorg. Med. Chem. 2009, 17, 1600.

18. Benchekroun, M.; Ismaili, L.; Pudlo, M.; Luzet, V.; Gharbi, T.; Refouvelet, B.; Marco-Contelles, J.; Future Med. Chem. 2015, 7,15 .

19. Catto, M.; Pisani, L.; Leonetti, F.; Nicolotti, O.; Pesce, P.; Stefanachi, A.; Cellamare, S.; Carotti, A.; Bioorg. Med. Chem. 2013, 21, 146

20. Kim, B.; Lee, S.; Jang, M.; Shon, M. Y.; Park, J. H.; Bull. Korean Chem. Soc. 2013, 34, 3322.

21. Lee, S. H.; Kim, B. C.; Kim, J. K.; Lee, H. S.; Shon, M. Y.; Park, J. H.; Bull. Korean Chem. Soc. 2014, 35, 1681.

22. Prezzavento, O.; Arena, E.; Parenti, C.; Pasquinucci, L.; Aricò, G.; Scoto, G. M.; Grancara, S.; Toninello, A.; Ronsisvalle, S.; J. Med. Chem. 2013, 56, 2447.

23. Estrada, M.; Perez, C.; Soriano, E.; Laurini, E.; Romano, M.; Pricl, S.; Morales-Garcia, J. A.; Perez-Castillo, A.; RodriguezFranco, M. I.; Future Med. Chem. 2016, 8, 1191.

24. Durrani, A. I.; Schwartz, H.; Nagl, M.; Sontag, G.; Food Chem. 2010, 120, 1143.

25. Holmquist, L.; Stuchbury, G.; Berbaum, K.; Muscat, S.; Young, S.; Hager, K.; Engel, J.; Munch, G.; Pharmacol. Ther. 2007, 113, 154.

26. Rosini, M.; Simoni, E.; Bartolini, M.; Tarozzi, A.; Matera, R.; Milelli, A.; Hrelia, P.; Andrisano, V.; Bolognesi, M. L.; Melchiorre, C.; Eur. J. Med. Chem. 2011, 46, 5435.

27. Koufaki, M.; Detsi, A.; Kiziridi, C.; Curr. Med. Chem. 2009, 16,4728 .

28. Bolognesi, M. L.; Minarini, A.; Tumiatti, V.; Melchiorre, C.; Mini-Rev. Med. Chem. 2006, 6, 1269.
29. Rosini, M.; Andrisano, V.; Bartolini, M.; Bolognesi, M. L.; Hrelia, P.; Minarini, A.; Tarozzi, A.; Melchiorre, C.; J. Med. Chem. 2005, 48, 360.

30. Barbe, G.; Charette, A. B.; J. Am. Chem. Soc. 2008, 130, 18.

31. Mühlhausen, U.; Ermert, J.; Herth, M. M.; Coenen, H. H.; J. Labelled Compd. Radiopharm. 2008, 52, 6.

32. Omura, K.; Swern, D.; Tetrahedron 1978, 34, 1651.

33. Huang, L.; Hao, X.; Mu, S.; Zhang, J.; CN pat. 102127006 B 2011 (CN 201010600277).

34. Gant, T. G.; Sarshar, S.; Shahbaz, M. M.; US pat. 20100143505 A1 2010 (US 12/633,992).

35. Stahl, G. L.; Walter, R.; Smith, C. W.; J. Org. Chem. 1978, 43, 2285.

36. Schieferdecker, S.; Nett, M.; Tetrahedron Lett. 2016, 57, 1359.

37. Luescher, M. U.; Vo, C.-V. T.; Bode, J. W.; Org. Lett. 2014, 16, 1236.

38. Szabo, M.; Klein Herenbrink, C.; Christopoulos, A.; Lane, J. R.; Capuano, B.; J. Med. Chem. 2014, 57, 4924.

39. Halim, M.; Tremblay, M. S.; Jockusch, S.; Turro, N. J.; Sames, D.; J. Am. Chem. Soc. 2007, 129, 7704.

40. Ellman, G. L.; Courtney, K. D.; Andres, V.; Featherstone, R. M.; Biochem. Pharmacol. 1961, 7, 88.

41. Greig, N. H.; Utsuki, T.; Yu, Q.; Zhu, X.; Holloway, H. W.; Perry, T.; Lee, B.; Ingram, D. K.; Lahiri, D. K.; Curr. Med. Res. Opin. 2001, 17, 159.

42. Molyneux, P.; Songklanakarin J. Sci. Technol. 2003, 26, 211.

43. Melagraki, G.; Afantitis, A.; Igglessi-Markopoulou, O.; Detsi, A.; Koufaki, M.; Kontogiorgis, C.; Hadjipavlou-Litina, D. J.; Eur. J. Med. Chem. 2009, 44, 3020.

44. Gehlhaar, D. K.; Verkhivker, G. M.; Rejto, P. A.; Sherman, C. J.; Fogel, D. R.; Fogel, L. J.; Freer, S. T.; Chem. Biol. 1995, 2, 317.

45. Thomsen, R.; Christensen, M. H.; J. Med. Chem. 2006, 49, 3315.

46. Fillion, E.; Fishlock, D.; Wilsily, A.; Goll, J. M.; J. Org. Chem. 2005, 70, 1316.

47. www.graphpad.com, accessed in October 2017.

48. Gülçin, İ.; Innovative Food Sci. Emerging Technol. 2010, 11, 210.

49. Nachon, F.; Carletti E.; Ronco, C.; Trovaslet, M.; Nicolet, Y.; Jean, L.; Renard, P.-Y.; Biochem. J. 2013, 453, 393.

50. Košak, U.; Knez, D.; Coquelle, N.; Brus, B.; Pišlar, A.; Nachon, F.; Brazzolotto, X.; Kos, J.; Colletier, J.-P.; Gobec, S.; Bioorg. Med. Chem. 2017, 25, 633.

51. Yang, J.-M.; J. Comput. Chem. 2004, 25, 843.

Submitted: September 5, 2017 Published online: October 31, 2017 